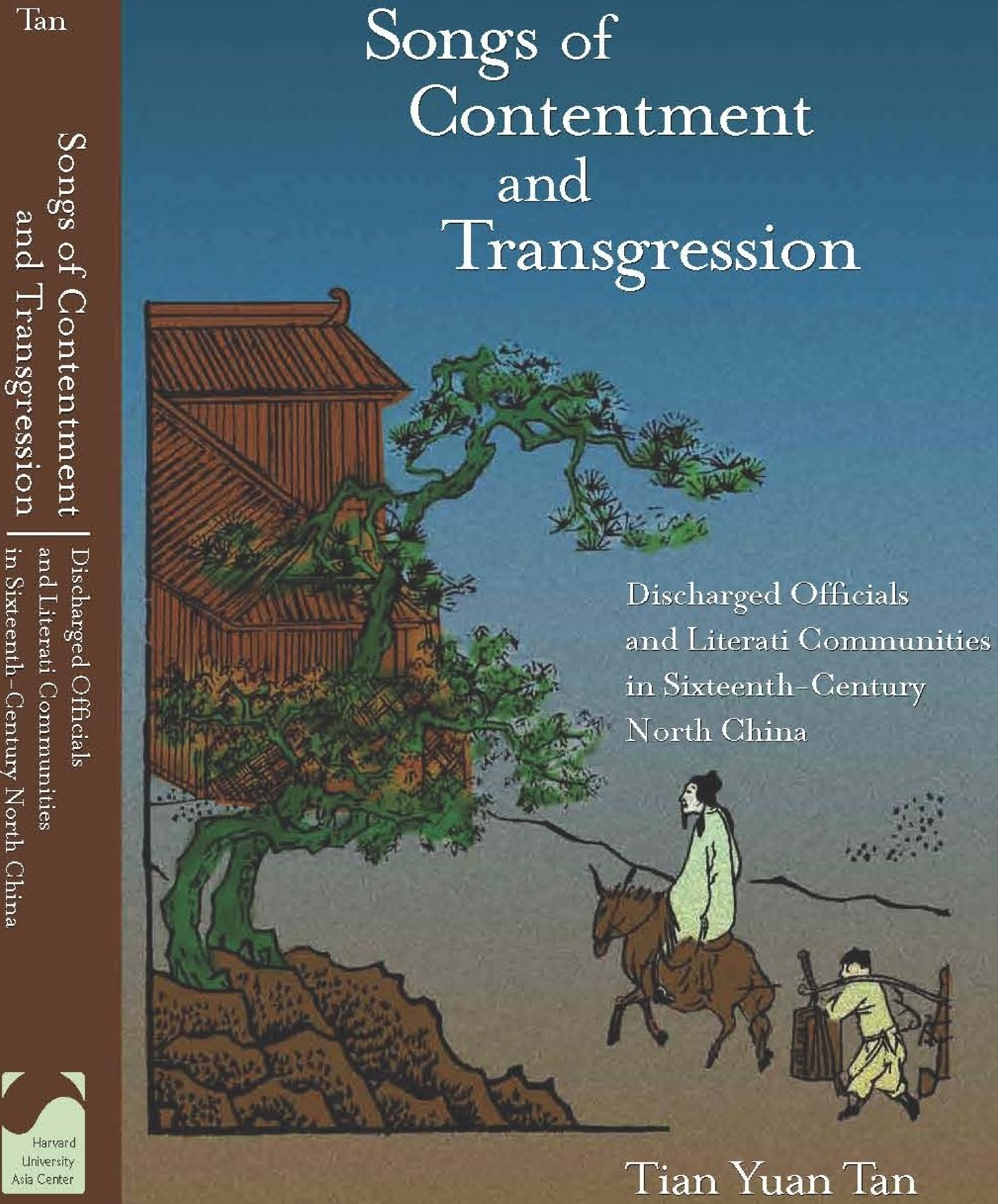




\title{
Songs of Contentment and Transgression
}

Discharged Officials and Literati Communities in Sixteenth-Century North China

\author{
Tian Yuan Tan
}

Published by the Harvard University Asia Center Distributed by Harvard University Press Cambridge (Massachusetts) and London 2010 
(C) 2010 by the President and Fellows of Harvard College

Printed in the United States of America

The Harvard-Yenching Institute, founded in 1928 and headquartered at Harvard University, is a foundation dedicated to the advancement of higher education in the humanities and social sciences in East and Southeast Asia. The Institute supports advanced research at Harvard by faculty members of certain Asian universities and doctoral studies at Harvard and other universities by junior faculty at the same universities. It also supports East Asian studies at Harvard through contributions to the Harvard-Yenching Library and publication of the Harvard Journal of Asiatic Studies and books on premodern East Asian history and literature.

\section{Library of Congress Cataloging-in-Publication Data}

Tan, Tian Yuan.

Songs of contentment and transgression : discharged officials and literati communities in sixteenth-century north China / Tian Yuan Tan.

p. cm. -- (Harvard-Yenching Institute monograph series ; 75)

Includes bibliographical references and index.

ISBN 978-0-674-05604-6

1. Qu (Chinese literature)--Ming dynasty, 1368-1644--History and criticism. 2. Chinese drama-Ming dynasty, 1368-1644--History and criticism. 3. Intellectuals--China--History--16th century. 4. China--Intellectual life--16th century. 5. Wang, Jiusi, 1468-1551. 6. Kang, Hai, 1475-1540. 7. Li, Kaixian, 1502-1568. I. Title.

PL2355.4.T37 2010

895.1 '244--dc22

2010008605

Index by the author

( Printed on acid-free paper

Last figure below indicates year of this printing

$\begin{array}{lllllllllll}19 & \text { I8 } & \text { I7 } & \text { I6 } & \text { I5 } & \text { I4 } & \text { I3 } & \text { I2 } & \text { II } & \text { IO }\end{array}$ 


\section{Contents}

Tables $\quad$ xii

Abbreviations $\quad$ xiii

Introduction $\quad$ I

Leaving the Center / I

Qu in Mid-Ming and North China / 6

Major Writers and Their Communities / 9

Part I: Wang Jiusi and Kang Hai in Shaanxi

I Paths into Qu Writing

Early Days in the Capital / I7

Dismissal in I5IO / 23

Qu as an Alternative yet Appropriate Genre / 3I

2 Performing Contentment and Dramatizing Retirement

Returning to My Fields / 39

The Tradition of Withdrawal Songs / 47

Rejecting Rejection / 55 
3 Writing in a Local Community

Tracing a Qu Community / 69

Beyond the Anthologies / 73

Song Matching / 75

Sharing a Subject / 88

4 A World of Their Own: Textual and Social Space

Songs for Occasions / II3

A Collection of Birthday Songs / IIs

Birthday Songs: Popularity, Styles, and Subjects / I3I

Creating Our World and Our Community / I42

\section{Interlude}

5 The Encounter Between the Masters of Two Generations and Two Locales

An Episode of Later Significance / I49

The Turning Point in I54I / I6I

\section{Part II: Li Kaixian in Shandong}

6 A Local Club and a Wider Community of Sanqu

A Qu Writing Club in Li Kaixian's Home Village / 169

Beyond the Local: From a Hundred Songs to Near a Hundred Colophons / I79

Providing a Template / I86

7 Drama Activities and $Q u$ Printing Projects

199

A Southern Play by a Northern Writer: Baojian ji / 200

Yuanben and the Tradition of One-Act Plays / 2II

Printing Projects / 218

8 The Master of Song and Drama

The Role and Influence of Li Kaixian / 227

The Making of a Master: Li’s Self-Fashioning / 230

Defense, Self-Justification, and Apologies / 235

The World of Qu Writing in Shandong After Li Kaixian / 240

Conclusion 
Appendix

Editions of Qu Writings Discussed 253

Reference Matter

Works Cited 265

Index 283 


\section{Abbreviations}

For complete bibliographical information, see the Appendix, pp. 25362, for $q u$ writings, or the Works Cited, pp. 265-8I, for other sources.

LMB Larrington Goodrich and Chaoying Fang, Dictionary of Ming Biography

GDYXCQ Li Kaixian, Gaiding Yuanxian cbuanqi 改定元賢傳奇

HXSRCDL Sishi Mu, comp., Huxi shanren chudulu湤西山人初 度錄

KDSXSJ Kang Hai, Kang Duishan xiansheng ji 康對山先生集

LKXQJ Li Kaixian, Li Kaixian quanji 李開先全集

MPWTS Wang Jiusi, Chongkan Meipi Wang taishi xiansheng quanji 重刊渼陂王太史先生全集

PDYF Kang Hai, Pandong yuefu 沜束樂府

PDYFHL Kang Hai, Pandong yuefu houlu 沜東樂府後錄

QMSQ Xie Boyang, ed., Quan Ming sanqu 全明散曲

QYSQ Sui Shusen, ed., Quan Yuan sanqu 全元散曲

SKQS Siku quanshu四庫全書

SKCM Siku quanshu cunmu congshu 四庫全書存目丵書 
SKCMBB Siku quanshu cunmu congshu bubian 四庫全書存目 丵書補編

WLQZLZ Kang Hai, Wang Lanqing zhenlie zhuan 王蘭卿眞[貞] 烈傳

XXSKQS Xuxiu Siku quanshu 續修四庫全書

YHYSKQ Lu Qian, ed., Yinhongyi suo ke qu 飲虹簃所刻曲

ZGGDXQ Zhongguo gudian xiqu lunzhu jicheng 中國古典戲曲論著 集成 


\section{Introduction}

\section{Leaving the Center}

Jingfu [zi of Wang Jiusi] and Dehan [zi of Kang Hai] were from the same area, served in the same office, and were both cashiered as members of Liu Jin's clique. Traveling between Pandong and Hu county, they visited each other and had conversations over banquets. They sought out songs and also composed tunes to amuse each other.

敬夫、德涵, 同里同官, 同以瑾黨放逐, 沜束、雲杜之間, 相與過從 談記, 徵歌度曲, 以相娱樂。1

[Li Kaixian] was promoted to the vice minister of the Court of Imperial Sacrifices. Because of a fire in the Imperial Ancestral Temple, he submitted his resignation [in accordance with the common practice], but he was actually dismissed. Upon his return to his native place, Li put the fields and estates in order. He kept singers, seeking out songs and also composing qu himself; he wrote songs to new tunes, plucking stringed instruments and singing without restraints. He was confident that even Ma Zhiyuan and Zhang Kejiu could not surpass him.

[李開先]已遷太常, 會九廟災, 上疏自陳, 竟罷歸。歸而治田產, 蓄聲 妓, 徵歌度曲, 虎新聲小令, 㧾彈放歌, 自謂馬束篗、張小山無以過 也。2

I. Qian Qianyi, Liechao shiji xiaozhuan, “Wang Shouzhou Jiusi” 王壽州九思, 314-I5.

2. Ibid., “Li Shaoqing Kaixian” 李少卿開先, 377. 
Officials in mid-Ming China discharged from their positions, whether through dismissal or forced retirement, faced a major turning point in their lives. From being at the center of society and enjoying a certain status, they found themselves suddenly displaced from the conventional path of success for a Chinese literatus. Where would they go and what would they do? How would they live out the rest of their lives? What pursuits would they choose?

In this book I explore the paths of three officials, Wang Jiusi 王九思 (I468I55I), Kang Hai 康海 (I475-I54I), and Li Kaixian 李開先 (I502-68), who in their estrangement from officialdom and politics, sought solace and contentment in literary endeavors. Their endeavors, however, diverged from the more formal writing expected of scholar-officials. This is a book about alternative literary paths and those who chose them.

The lives of these three literati share certain similarities. All three were once scholar-officials who had been successful in the imperial examinations (Kang Hai was even the top graduate) and been appointed to significant official posts but were later dismissed or forced to retire to their home villages for the remainder of their lives: 27 years in Li's case, 30 in Kang's, and 40 in Wang's. In the prime of their lives, these men were suddenly displaced from the political center and diverted from the conventional path of success for a Chinese literatus. In retirement, all engaged actively in writing drama and songs in the $q u$ 曲 genre.

The term $q u$ literally means "songs," and in traditional terminology as used and understood in the Ming dynasty (I368-I644), ${ }^{3}$ it refers to both sanqu 散曲 ${ }^{4}$ (literally, “dispersed or individual songs"), a kind of song verse in Chinese literature, and juqu 劇曲 (drama, also now commonly designated as xiqu 戲曲). ${ }^{5}$ In this study, I follow this convention

3. Li Changji, Zhongguo gudai quxue shi, 47. In addition, in qu anthologies, the differentiation between sanqu and drama became more distinct only in the Wanli (1573-1620) period; see Zhu Chongzhi, Zhongguo gudai xiqu xuanben yanjiu, I5.

4. Ming writers also often referred to their sanqu writings as $c i$ 詞 or $y$ uefu 樂府.

5. At the beginning of the twentieth century, Wang Guowei 王國維 (I877-1927) used the term xiqu for his seminal study of the history of Chinese drama. As Patricia Sieber (Theaters of Desire, 22-24) has pointed out, this was "a significantly modern and highly influential linguistic choice." Wang's coinage was most likely related to the Japanese concept of gikyoku (itself a loanword from classical Chinese and written with the same Chinese characters as xiqu) and quickly became diffused into Republican-era parlance. 
and use the term $q u$ to designate song and drama. I also call all literati who participated in the writing of sanqu or drama " $q u$ writers."

Why did these three literati choose to pursue the qu genre? $Q u$ was certainly not the most natural literary genre for a traditional Chinese scholar. Unlike the more formal genres such as prose or shi poetry that every Chinese literatus was expected to write, sanqu and drama were often regarded as "pastimes" unworthy of the literati's attention. They thus suffered from a lower status compared to high and serious genres such as poetry and prose. The mid-Ming literatus He Liangjun 何良俊 (I506-73), a contemporary of Li Kaixian, once pointed out that scholarofficials felt ashamed to pay attention to lyrics and $q u \cdot{ }^{6}$ Furthermore, $q u$ rarely appeared in the literary collection (wenji 文集) of a Chinese writer, an absence that implies $q u$ was not regarded as part of one's standard literary corpus. This tells us much about the marginal status of the genre. $^{7}$

This book traces a connection between a disappointing end to an official career and the embrace of $q u$, between a physical move away from the center and the pursuit of a marginalized literary genre. Wang, Kang, and Li did not write a few songs. Each wrote hundreds of sanqu songs and a number of plays, discussed in detail in the chapters that follow. In fact, from the I5IOs to I560s, these three literati became the major $q u$ writers in north China. Wang Shizhen's 王世貞 (I526-90) later remark "Among the northerners, since Wang Jiusi and Kang Hai, one has to mention Li Bohua [ $2 i$ of Li Kaixian] from Shandong 北人自王、康 后，推山束李伯華" 8 indicates the renown of this trio.

However, along with fame, their attention to such a marginalized genre as song and drama also attracted criticism, especially concerning their lifestyles. For a literatus, the proper path of study and conduct was Confucian learning and statecraft. It was definitely not writing lyrics, songs, or plays. Consider, for example, the reception Kang Hai received from his contemporaries, as described in Li Kaixian's biography of him:

6. He Liangjun, Qulun, 6.

7. One may compare this to the analogous status of the $c i$ lyric in the Northern Song; see Egan, "The Problem of the Repute of Ci," and his more recent The Problem of Beauty, esp. 24I-50.

8. Wang Shizhen (I526-90), Quzao, 36. 
"For whenever [Kang Hai] drank, he was always accompanied by singsong girls; wherever there were singsong girls, there would be songs, and whenever there were songs, they were always written by himself; thus his contemporaries criticized him for being too unrestrained" 或 又以其酒必妓，妓必歌，歌必自製，病其太放. ${ }^{9}$ Literati society envisioned the world of $q u$ as limited to wine, music, and singsong girls and looked down on it. The disparagement of $q u$ reached new heights in the eighteenth century, exemplified in statements by the editors of Mingshi 明史 (Standard history of the Ming dynasty) and Siku quanshu 四庫全書 (Complete collection of the four treasuries). ${ }^{10}$ Kang Hai was heavily criticized for his "indulgence" in these genres:

In order to save Li Mengyang, Kang Hai lost his integrity through association with Liu Jin. As Liu Jin fell from power, Kang Hai was punished [as an accomplice] and was dismissed. Thereafter, he became completely given to sensual pleasures without any restraint, calling for singers and gathering singsong girls around him. He no longer devoted his attention to essays and prose, and his poetry became most depraved and unruly.

海以救李夢陽故失身劉瑾, 瑾敗坐廢, 遂放浪自恣, 徵歌選妓, 於文 章不復精思, 詩尤頽縱。11

In this account, Kang Hai adopted a decadent and unrestrained lifestyle following his dismissal from office, forsaking the more "proper" genres such as prose and poetry and indulging in "wine, women, and songs." Sometimes it was even implied that a wanton lifestyle was "essential" for one to excel in the qu genre:

Kang Hai, in his late years, indulged his passions among singsong girls and therefore [italics added] he excelled in yuefu [i.e., sanqu]. He did not pay much at-

9. Li Kaixian, “Duishan Kang xiuzhuan zhuan” 對山康修撰傳, LKXQJ, 762.

IO. This was most clearly shown in the disparaging assessment of the qu genre by the eighteenth-century compilers of the catalog of the imperial library at the head of the section devoted to lyrics and arias (ciqu 詞曲), in Yong Rong et al., Siku quanshu zongmu, 198.I807: " $\mathrm{C} i$ and $q u$ are two genres that are between literature and professional skills. They are of a rather inferior grade and are not highly regarded by writers. It is just the 'clever' literati who compete with one another using such extravagant phrases” 詞、曲 二體, 在文章、技藝之間, 厥品頗卑, 作者弗貴, 特才華之士, 以綺語相高耳.

II. Ibid., I7I.I499. 
tention to his poetry and prose. Hence, his sharpness [in $q u$ ] and bluntness [in poetry and prose] could not but show against each other.

海晚歲縱情聲伎, 故樂府特孚擅長。詩文皆不甚留意, 不免利鈍 互陳。12

Also implied in these two remarks is that writing $q u$ might affect one's talent in other genres and damage the ability of a literatus like Kang Hai to engage in "serious" writing. According to some critics, the harm of writing $q u$ went beyond that. This is what the editors of Mingshi said about the lifestyles of Kang Hai and Wang Jiusi following their dismissals:

Whenever they gathered in Pandong or Hu county, they brought along singsong girls and drank rapturously. They created music and produced songs, comparing themselves to actors, so as to give expression to their frustration and sorrow. Wang Jiusi once paid a huge sum in acquiring musicians in order to learn to play the pipa, and Kang Hai was especially apt in plucking string instruments. Later, people spread stories about them and followed their example. The way of great elegance and refinement indeed declined.

每相聚沜束、零杜間, 㣣聲伎酣飲, 製樂造歌曲, 自比俳優, 以寄其

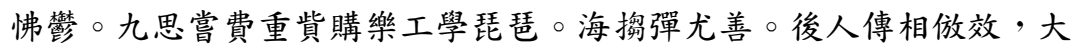
雅之道微矣。13

Music, wine, and singsong girls were not appropriate companions for a serious gentleman. Hence, in the eyes of the editors of Mingshi, the writing of $q u$ became a "harmful" and abhorrent act because followers of Wang and Kang imitated not only their literary styles but also their lifestyles, which certainly did not follow the path of proper conduct.

A stigma was clearly attached to these genres both during and after the mid-Ming partly because the ambience of $q u$ writing often involved singsong girls, wine, and sensual pleasures. Wang, Kang, and Li did not write $q u$ for profit in the commercial theater or for court performances under imperial patronage. In other words, they were not writing for a living. If these literati were aware of negative comments about their involvement in $q u$ activities - and in the following chapters I show that

I2. Ibid., I76.1567.

I3. Zhang Tingyu et al., Mingshi, 286.7349. 
they were — why did they still participate in this genre, and how did they themselves perceive the writing of qu?

We have to consider carefully the relation between the forced retirement of Wang, Kang, and $\mathrm{Li}$ and their conspicuous involvement in $q u$ writing. Two imperial kinsmen, Zhu Youdun 朱有燉 (I379-I439) and his uncle Zhu Quan 朱權 (I378-I448), were similarly involved in qu, but their adoption of the genre might be seen as a self-protective means of demonstrating their lack of interest in politics in order to survive the power struggles within the imperial family. ${ }^{14}$

The literati writers presented in this book, however, faced a different situation. Suddenly displaced from official life, they were more concerned with finding a new channel for their old ambitions rather than hiding them like the royal playwrights. How did qu writing, perhaps even simply the act of taking up such a genre and the decadent lifestyle associated with it, serve the needs of these rejected literati in the first half of the sixteenth century? To begin to answer this question, we must first examine the place of $q u$ writing in the Ming period.

\section{$\mathrm{Qu}$ in Mid-Ming and North China}

Recent years have seen a growing awareness of the lack of scholarship on early Ming literature, which is no less interesting and significant than the literature of the well-researched late Ming period. ${ }^{15}$ For the field of $q u$ studies, the mid-Ming, roughly I450-1550, is especially important for understanding the development of song and drama. This was the period that witnessed a revival in $q u$ writing.

The Yuan dynasty (I260-I368) is often regarded as the golden age of $q u$. A number of late Yuan $q u$ writers continued to be active in the early decades of the Ming dynasty, ${ }^{16}$ but whereas $q u$ thrived during the Yuan

I4. Idema, The Dramatic Oeuvre of Chu Yu-tun, I8.

15. This point is underlined in Kang-i Sun Chang's chapter on early and mid-Ming literature in the forthcoming The Cambridge History of Chinese Literature. Daniel Bryant's recently published The Great Recreation: Ho Ching-ming (1483-I52I) and His World is a significant contribution and redresses the neglect in scholarship on poetry of the midMing. In his preface, Bryant points out "how relatively little has been written about the period and the people with whom this book is concerned" (xvi-xvii).

I6. See, e.g., the sixteen $q u$ writers listed in Zhu Quan, Taibe zhengyin pu, 22-23. 
dynasty in commercial theaters and urban centers and appears to have been enjoyed by people of all classes, in the early Ming the genre was largely associated with regional courts and the two capitals in Beijing and Nanjing. For example, writers such as Tang Shi 湯式 (fl. I383), Yang Ne 楊訥 (fl. I4O2), and Jia Zhongming 賈仲明 (I343-I422) enjoyed the patronage of the Yongle emperor (r. I402-24) when he was still the Prince of Yan in Beijing. ${ }^{17}$ Furthermore, the most prolific and important $q u$ writer in the first half of the fifteenth century was Zhu Youdun, the Exemplary Prince of Zhou in Kaifeng. The next few decades of $q u$ activities continued to be dominated by court writers and performers writing and producing songs and dramas for palace entertainment and consumption. The early Ming was an age of anonymous $q u$ writing in which few writers of songs and dramas were known.

It was not until the mid-Ming that a new generation of $q u$ writers broke through this anonymity. Interestingly, their emergence was a distinctively local phenomenon; for example, in Nanjing, with Chen Duo 陳鐸 (I454?-I507?) and Xu Lin 徐霖 (I462-I538) ${ }^{18}$; in Suzhou, with writers such as Tang Yin 唐寅 (I470-I523); and in Yunnan, with Yang Shen 楊壃 (I488-I559). This marked the transition from the court to the private realm as the site of $q u$ production. At this time, more literati writers came to be associated with the qu genre.

This was the vibrant literary world inhabited by our three discharged officials, Wang Jiusi, Kang Hai, and Li Kaixian. My approach to exploring song and drama in a particular region is informed by the emergence of local centers of qu production during the mid-Ming. Although I begin with a discussion of these three major $q u$ writers, I show that they did not create their worlds of song and drama as solitary outcasts. More literati were involved in these writing activities than literary histories have suggested. Hence, in exploring the worlds of these three writers, Kang and Wang in Shaanxi and Li in Shandong, we are moving toward uncovering two local centers of $q u$ production surrounding these literati.

This book is the first attempt to sketch the rich literary landscape of mid-Ming north China, a world still largely unknown to us. Previous

17. Luguibu xubian, 283-84, 292. See also Idema, The Dramatic Oewvre of Chu Yu-tun, 2IO-33.

I8. See Tian Yuan Tan, "Emerging from Anonymity." 
studies have observed that the period from the late fifteenth to the first half of the sixteenth century witnessed the rise of southern chuanqi 傳 奇 drama and the decline of northern raju 雜劇 drama. As a result, for a long time, the development of Chinese drama in the second half of the Ming dynasty has often conveniently been represented by the rise of the southern chuanqi in south China in standard literary historical accounts. By contrast, little has been written about the theatrical world in north China. This gap is well illustrated in Xu Shuofang's 徐朔方 important work on Ming playwrights, Wan Ming qujia nianpu 晚明曲家年 譜 (Chronological biographies of late Ming $q u$ writers). Xu's work covers $q u$ writers active from I522 to 1644 and even includes some born as early as I462. However, all of the biographies are from southern China, specifically from three southern regions considered the most "representative" of the late Ming period, which produced the greatest number of $q u$ writers. ${ }^{19}$ Northern $q u$ writers have been left out. In a similar fashion, previous studies on sanqu songs have focused on the Yuan dynasty, often regarded as the golden age of sanqu. ${ }^{20}$ We face an even larger gap in this field in Western scholarship. Almost all previous studies on and translations of sanqu deal only with Yuan sanqu. ${ }^{21}$ To rediscover such an unexplored literary world, it is essential not only to look at major writers like Kang, Wang, and Li but also to draw into our discussion other $q u$ writers surrounding these figures who have been overlooked and are invisible in literary histories.

19. The three volumes of Xu Shuofang, Wan Ming qujia nianpu, are devoted to Suzhou 蘇州, Zhejiang 浙江, and Wan'gan 皖贑 (i.e., Anhui, Jiangxi), respectively.

20. He Guichu's index to sanqu studies, Yuan Ming Qing sanqu lun₹̧bu suoyin, makes it clear that previous scholarship is overwhelming on Yuan sanqu. Not until 2007 was a monograph on the developments of sanqu after the Yuan dynasty published; see Zhao Yishan, Ming Qing sanqu shi.

2I. See, e.g., Crump, Songs from Xanadu; idem, Song-Poems from Xanadu; Radtke, Poetry of the Yuan Dynasty; Richard F. S. Yang and Metzger, Fifty Songs from the Yuan; and Schlepp, San-ch' $\ddot{u}$. In The Columbia History of Chinese Literature, the genre of sanqu is discussed only under the chapter on Yuan dynasty sanqu; sanqu developments in the Ming dynasty are summarized in a few lines in the concluding paragraph of the chapter; see Schlepp, "Yüan San-chü." 


\section{Major Writers and Their Communities}

When we speak of writers in the Ming dynasty, the names that immediately come to mind - for example, the Former and Later Seven Masters, the Gong'an and Jingling schools - betray the general practice of considering writers in relation to the literary circles to which they belonged.22 A writer might live, work, and write in multiple and sometimes overlapping literary circles. Wang Jiusi and Kang Hai are often referred to as members of the famous "Former Seven Masters" (Qian qi $2 i$ 前七子), and Li Kaixian is well known as one of the "Eight Talents of the Jiajing Period (I522-67)" (Jiajing ba caiæi 嘉靖入才子). These literary circles were based on the poetry and prose or shared literary ideals of their members. But Kang Hai, Wang Jiusi, and Li Kaixian did not write poetry or prose exclusively and are perhaps even more renowned for their sanqu and drama.

It is interesting to note that these three literati did not write primarily sanqu and drama in the literary circles of the Seven Masters or the Eight Talents. With whom and to whom, then, did they write sanqu songs and drama? The modern sanqu anthologies often select works of theirs that portray them as "individual" writers and exclude their "social" pieces. If we go beyond these representative pieces, we learn that Wang, Kang, and $\mathrm{Li}$, in writing $q u$, were not isolated authors working on their own, nor did they write only to one another. Rather, surrounding these three $q u$ masters were other literati who also participated in $q u$ activities.

This book adopts a new approach to the study of these dramatists and sanqu writers in Chinese literary history. I study Wang Jiusi, Kang $\mathrm{Hai}$, and Li Kaixian not as solitary writers but as signposts to less visible

22. In studying literary groups in the Ming dynasty, one must mention Guo Shaoyu's "Mingdai de wenren jituan." For more recent studies of literati groups during the late Ming to early Qing dynasty, see He Zongmei, Mingmo Qingchu wenren jieshe yanjiu, esp. I770; and Li Shenghua, Wan Ming shige yanjiu, which studies the different poetry "schools" and clubs in the late Ming. For a more general study of literary groups in Chinese literary history, see Guo Yingde, Zhongguo gudai wenren jituan yu wenxue fengmao. Studies on literary circles in other periods include Hu Dalei, Zhonggu wenxue jituan; Jia Jinhua, Tangdai jibui zongji yu shiren qunti yanjiu; Ouyang Guang, Song Yuan shishe yanjiu conggao; and Xie Zhengguang, Qingchu shiwen yu shiren jiaoyou kao. For a more general study of societies in Chinese culture, see Chen Baoliang, Zhongguo de she yu bui. 
participants in the genre, signposts that give us access to the entire world of sanqu and drama among the literati. In many ways, these discharged officials were cultural leaders in their native regions. I consider them major $q u$ writers, not only because of their skills and knowledge of the genre, but also because of their social status and wealth, which established them as central figures in their individual qu circles.

The songs and dramas of Wang, Kang, and $\mathrm{Li}$ are especially useful and attractive for a study of this nature. They preserve rich information on the context in which $q u$ writing was undertaken, including by whom and to whom $q u$ writings were composed and also the occasions on which they were produced. ${ }^{23}$ Hence, we can explore the range of $q u$ activities and the number of participants by examining their $q u$ writings.

I use "qu writings" to refer to all writings related to the various modes of $q u$ production, transmission, and reception. ${ }^{24}$ The emphasis is not only on the contents of these songs and dramas but also on their social context. I focus on drama and sanqu compositions, compilations, and anthologies and pay attention to all the related prefaces ( $x u$ 序), colophons ( $b a$ 跋), and any other materials that contain information on the context of $q u$ activities.

In collecting such $q u$ writings, I have made a conscious effort to consult original Ming and Qing printed editions and hand-copied manuscripts, instead of relying on modern editions, collections, and anthologies, for two reasons. First, modern anthologies and collections of drama and sanqu in the Ming dynasty are inadequate. For example, the five-volume Quan Ming sanqu 全明散曲 (A collection of sanqu in the entire Ming dynasty) is an indispensable reference work for the study of Ming dynasty sanqu, but it is not a complete collection of the sanqu produced in the Ming dynasty. By returning to the original sources used in this study, one can discover many more sanqu writers and writings in the various printed editions and manuscripts of $q u$ writings. (For a list of such previously unknown, "new" qu writers and their qu writings, see

23. Such information is similar to what Lauro Martines has called "direct reference" in his quest for the connection between English Renaissance verse and its social world; see Martines, Society and History in English Renaissance Verse, 20-2I.

24. For a list of all $q u$ writings discussed in this study, with bibliographic details on their various editions, see the Appendix. 
the Appendix. $)^{25}$ Second, although modern critical editions are often neater and tidier, important information about the context of each printing and edition is sometimes omitted, probably because the editors considered such materials "unliterary" and irrelevant.

We rarely find among other mid-Ming literati, at least in their extant writings, such relatively well documented, interconnected groups collectively participating in the various modes of $q u$ production, transmission, and reception as we see in the case of Wang, Kang, and Li. ${ }^{26} \mathrm{I}$ call these groups of literati that formed around these major $q u$ writers " $q u$ communities."

Community is a complicated sociological concept that has given rise to a wide range of different interpretations and emphases in research. Running through most conceptions of community is, however, a common focus on three themes or elements: the social class of the members or participants, their spatial connection, and their shared interests or values. ${ }^{27}$ In this study, I argue that participation in a genre defines a community.

One inspiration for my thinking about these qu writers and my approach to studying them is Pierre Bourdieu's literary sociology, especially his concepts of the literary field, writers' positions and position-takings in it, and symbolic and cultural capital. ${ }^{28}$ A "literary field," a term coined by Bourdieu, is a social universe with its own laws of functioning and specific relations of force in which literary works are produced. ${ }^{29}$ I suggest that the $q u$ genre, as a subfield in the "literary field" of sixteenthcentury north China, also has its own laws of functioning and distinct

25. Writers and works marked with an asterisk in the Appendix are those from original sources and not included in QMSQ.

26. This, however, became increasingly common in the late Ming. For example, the sanqu writings of Chen Suowen 陳所聞 (I526?-after 1605) usually have long titles containing the dates and occasions on which the songs were written as well as the names of $q u$ writers who participated.

27. See Campbell, "Social Structure, Space and Sentiment."

28. I rely mainly on Bourdieu's Field of Cultural Production and Rules of Art. The scholar who has actively introduced Bourdieu's literary concepts to the study of modern Chinese literature is Michel Hockx; see Hockx, "Introduction"; and idem, "Theory as Practice."

29. Bourdieu, "Field of Power, Literary Field and Habitus," in idem, Field of Cultural Production, I63. 
level of symbolic and cultural capital that writers gained by taking up the genre.

By using "qu community" as the basic unit in the study of sanqu and drama, we can also see how songs and dramas were produced, transmitted, and "used" among these writers, things less evident when we focus only on individual writers. ${ }^{30}$ Studies on literary communities have encouraged us to "move away from the idea of the abstract individual as the producer of literary texts." 31 The social and communal nature of $q u$ writing addressed in this book may be compared with recent studies on the social exchange of Chinese art and literature, such as Craig Clunas's study of the social art of Wen Zhengming 文徵明 (I470-I559) or Colin Hawes's study on the social circulation of poetry in the midNorthern Song. ${ }^{32}$

The amount of material and the wide-ranging activities of Wang, Kang, and Li easily warrant a separate study on each. I chose to undertake a collective study of all three, however, because of the style of their writings and the nature of their interactions. Separate studies could not fully reveal such crucial phenomena.

These three literati represent two overlapping generations of $q u$ writers active in the first half of the sixteenth century. Wang and Kang were about a generation older than Li. We can divide the main course of their activities, which spanned almost seven decades, into three periods. The first period starts in I5OI when Kang and Wang met in the capital ( $\mathrm{Li}$ was born a year later, in I5O2) and ends before $\mathrm{1531}$, the year $\mathrm{Li}$ paid

30. This concept of a " $q u$ community" is applicable to other periods in the history of Chinese drama and sanqu as well. For example, Wang Shih-pe has applied this concept in her study of Yuan playwrights and songwriters, "Cong Yuankanben chongtan Yuan zaju," 244. Wang traces three qu communities among southern writers and states that a similar approach could be applied to the northern writers of the Yuan dynasty as well (ibid., esp. 252-55).

3I. Cox, Poetry and Politics in the Cockney School, 5. Cox, in his study of romantic poets, offers the "group" as a key site for cultural production. Similar concerns and approaches can also be found in Summers and Pebworth, Literary Circles and Cultural Communities in Renaissance England. My discussion of the socialized mode of literary production in a community has also benefited from Arthur Marotti's study of the transmission of English Renaissance lyrics in his Manuscript, Print, and the English Renaissance Lyric.

32. See Clunas, Elegant Debts; and Hawes, The Social Circulation of Poetry in the MidNorthern Song. 
a visit to Wang and Kang in Shaanxi. The second period, from I53I to I54I (the year Kang passed away), is the only period in which all three could have possibly been in contact. The final period features Wang and Li for the first decade, until I55I when Wang passed away, and then only Li until his death in $\mathrm{I} 568$. It is therefore clear that, instead of functioning as one cohesive group in $q u$ writing, these three discharged officials were largely writing $q u$ in two different, though not exclusive, regions and periods, and are best regarded as central figures in two successive $q u$ communities in Shaanxi and Shandong, respectively.

This book is divided into two parts, with an interlude in between, based on these different periods in the lives of Kang, Wang, and $\mathrm{Li}$ and their subsequent impact on the larger world of song and drama around them.

Part I focuses on the formation of the Shaanxi community around Wang Jiusi and Kang Hai. Chapter I traces the paths of these two major writers into $q u$ writing. Taking up the $q u$ genre was an act of high visibility. Drawing on their own writings, the chapter explains why $q u$, as an alternative genre, suited these two rejected literati. Chapter 2 continues to explore what the $q u$ genre offered them by illustrating how Wang and Kang used song and drama as a performance of their contentment and a way to reinvent an alternative and idealized path to retirement. The next two chapters move from the two major writers to the local Shaanxi community that formed around them. Chapter 3 shows how we may use the major writers as signposts to their communities and illustrates the function of sanqu as social and occasional writings in such a community. This chapter explores various modes of collective writing such as the practice of song matching and the sharing of a common subject matter in sanqu and drama and demonstrates how the practice formed a communal textual world. Chapter 4 focuses on the conflation of the textual and social worlds of the qu community, especially in the case of birthday songs, and argues that this communal world functioned as a world of their own for the discharged officials.

Chapter 5, an interlude, looks at the encounter between these major $q u$ writers of two generations and two locales from I53I to I54I. It begins with the I53I visit by the young Li Kaixian to the two senior masters, Wang and Kang, in Shaanxi. Li's decision to write an extremely 
long song suite dedicated to Kang Hai on their first meeting once again brings us back to the issue of the choice of genre. Then, we explore a major turning point in the literary scene of mid-Ming north China: In I54I, Kang passed away and Li Kaixian returned to Shandong in forced retirement. We look at how the loss of one leader (Kang Hai) in Shaanxi and the emergence of another (Li Kaixian) in Shandong transformed the dynamics of the two local qu communities.

This sets the stage for Part II, which focuses on the world of song and drama in Shandong with Li Kaixian at its center. In Chapter 6, we look at a local $q u$ writing club in Li's home village and discuss how textual circulation enabled $q u$ writings to travel beyond the local context and reach a much wider community of readers and commentators. This discussion utilizes a set of one hundred songs written by Li that initiated a large-scale and quasi-national level of song matching and colophon writing. Chapter 7 then discusses the drama activities and various $q u$ printing projects of Li. In Chapter 8, I examine Li's role and influence in the Shandong $q u$ community and argue that his path to becoming the leader of this community may be perceived as a selffashioning process. I also look at Li's many defenses, apologies, and self-justifications for his involvement in song and drama, which remind us again of the alternative nature of his pursuits in the genre. In a brief concluding chapter, I discuss where the findings of this study lead us in terms of a reconsideration of the world of $q u$ writing in the contexts of sixteenth-century north China and beyond. 